\title{
Notes on the vocalizations of Citrine Warbler (Basileuterus luteoviridis)
}

Peter Boesman

In the following we briefly analyze and compare voice of the different races of Citrine Warbler (Basileuterus luteoviridis). We also try to quantify the extent of any vocal differences using the criteria proposed by Tobias et al. (2010), as a support for taxonomic review.

We have made use of sound recordings available on-line from Xeno Canto (XC) and Macaulay Library (ML).

An overview of song per race, illustrated with sonograms:

richardsoni (Pacific slope W Andes) ( $n=2)$
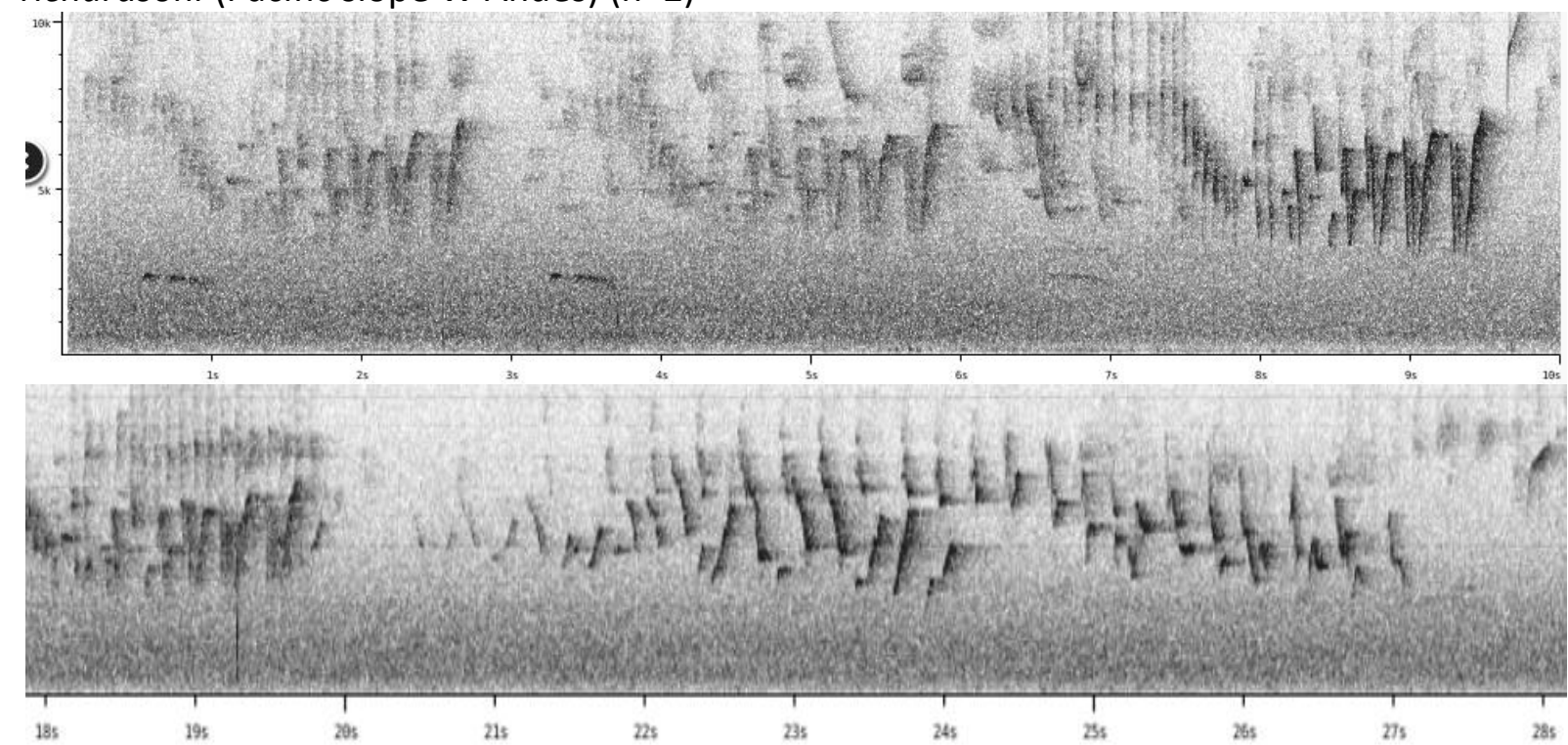

quindianus (C Andes Colombia)

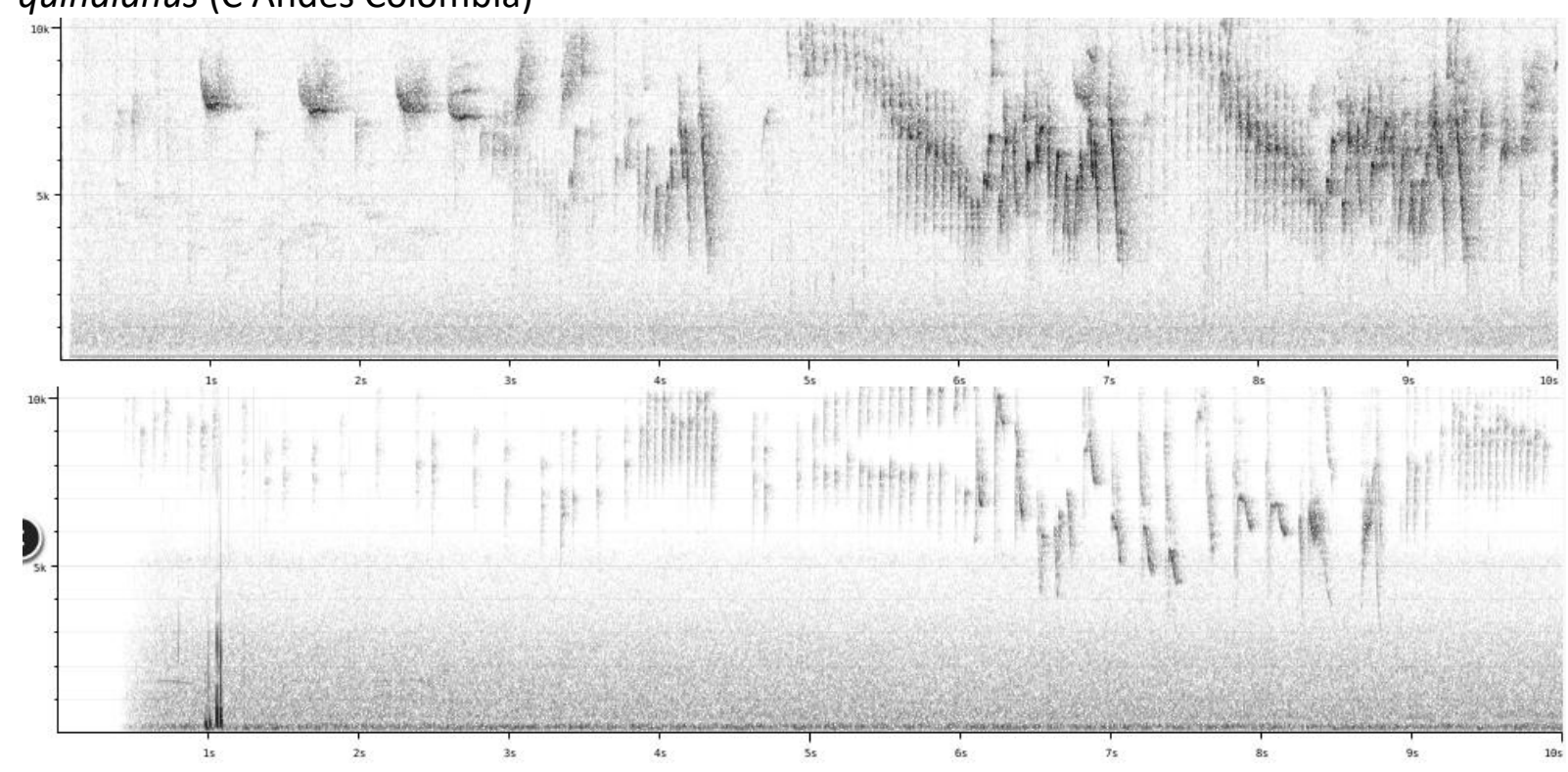




\section{HANDBOOK OF THE BIRDSPFGTE WORLD}

\section{ORNITHOLOGICAL NOTES}

nominate

Venezuela ( $\mathrm{N}$ of Tachira gap)

duet twitter

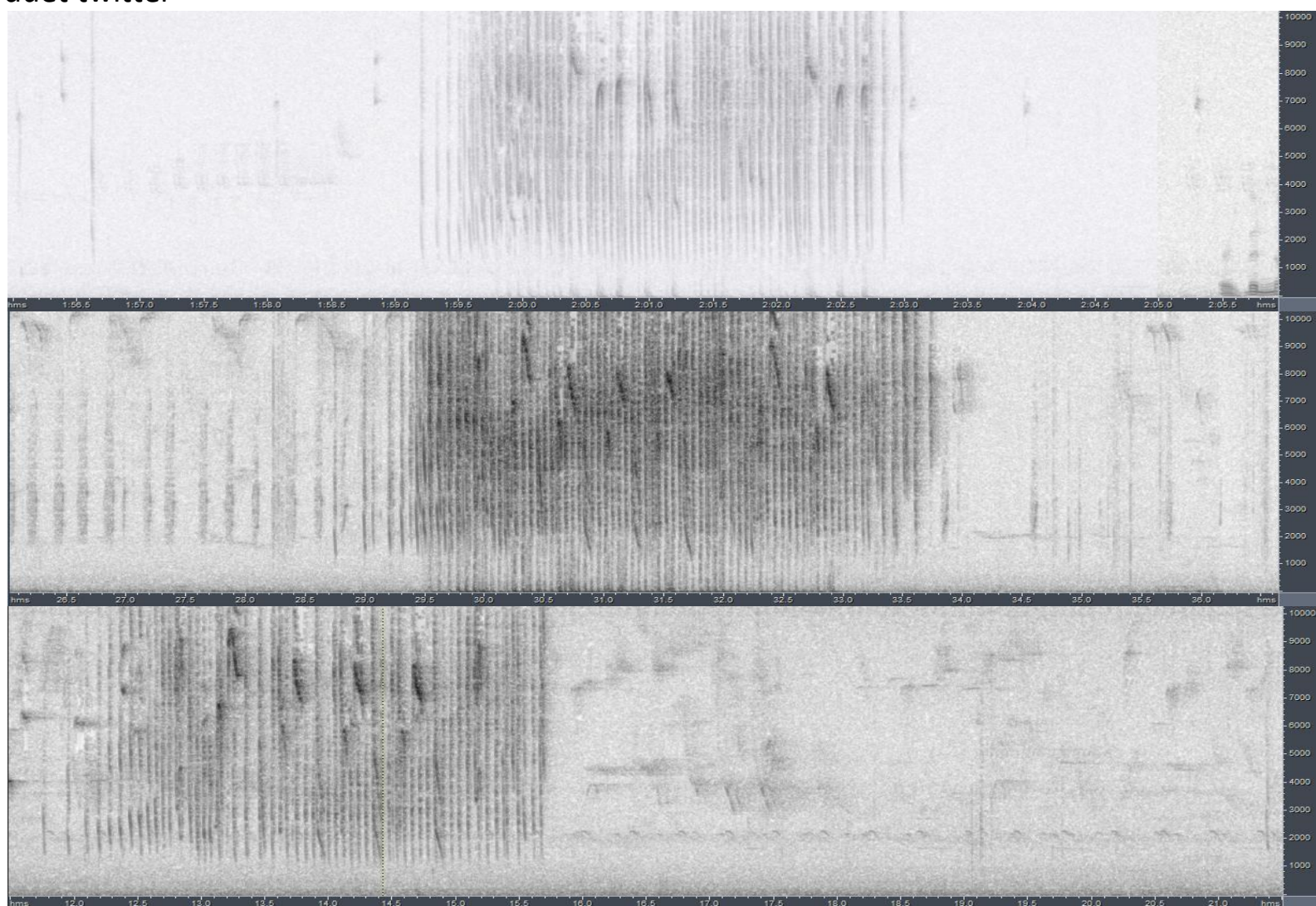

\section{E Andes Colombia}

song

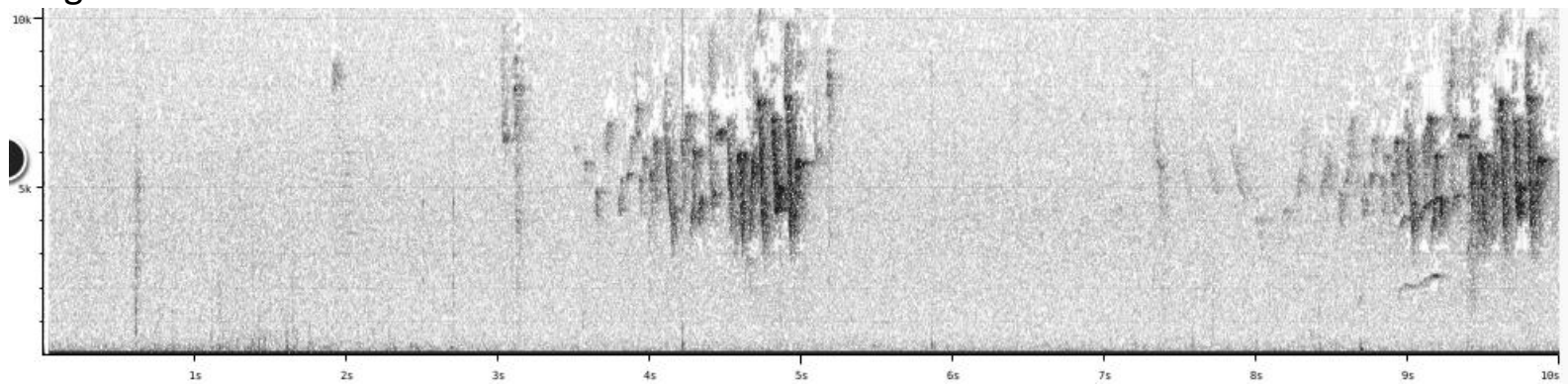

E Andes Ecuador

song

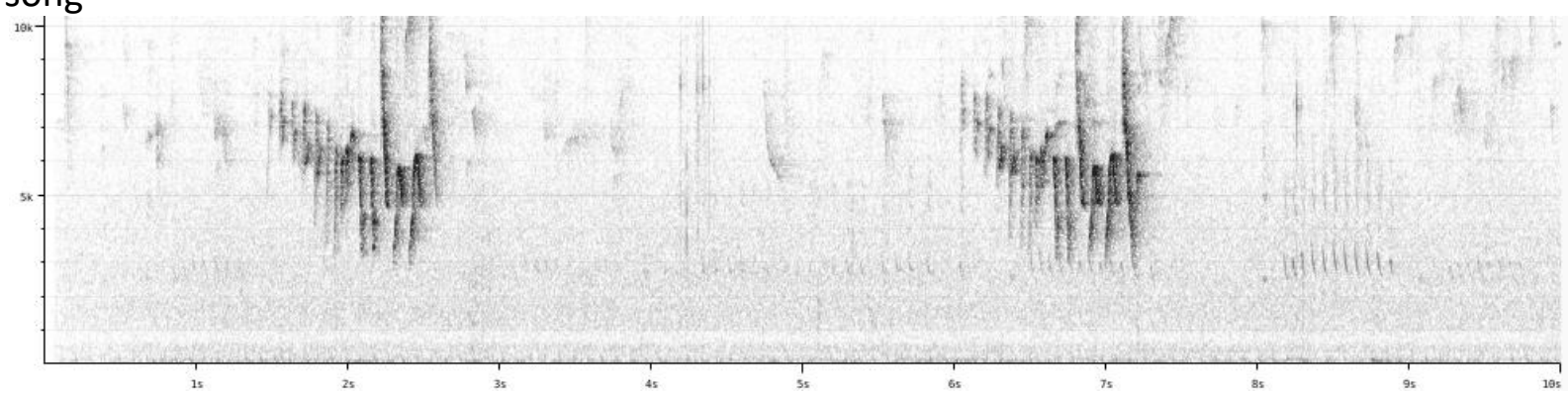


HANDBOOK OF THE

Alve

ORNITHOLOGICAL NOTES

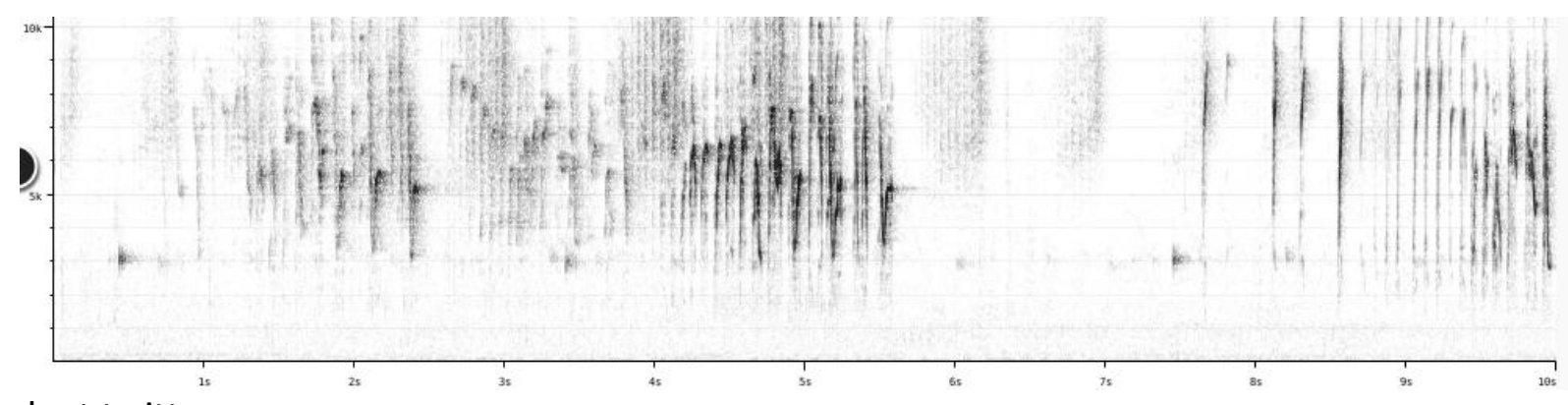

duet twitter

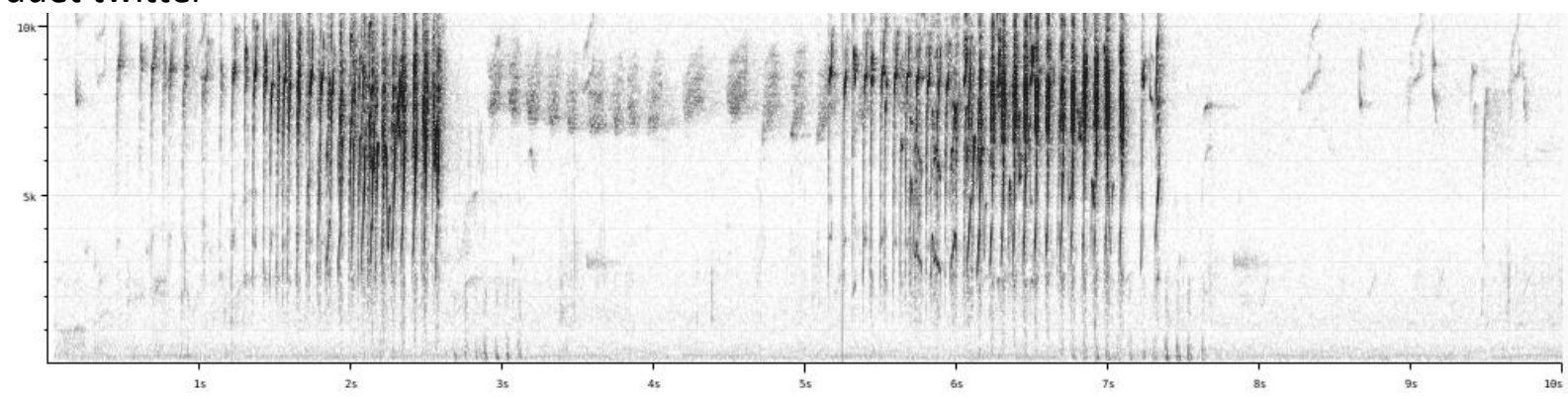

striaticeps

N Peru

song

$\underbrace{(200}_{i s}$

duet (song and twitter)

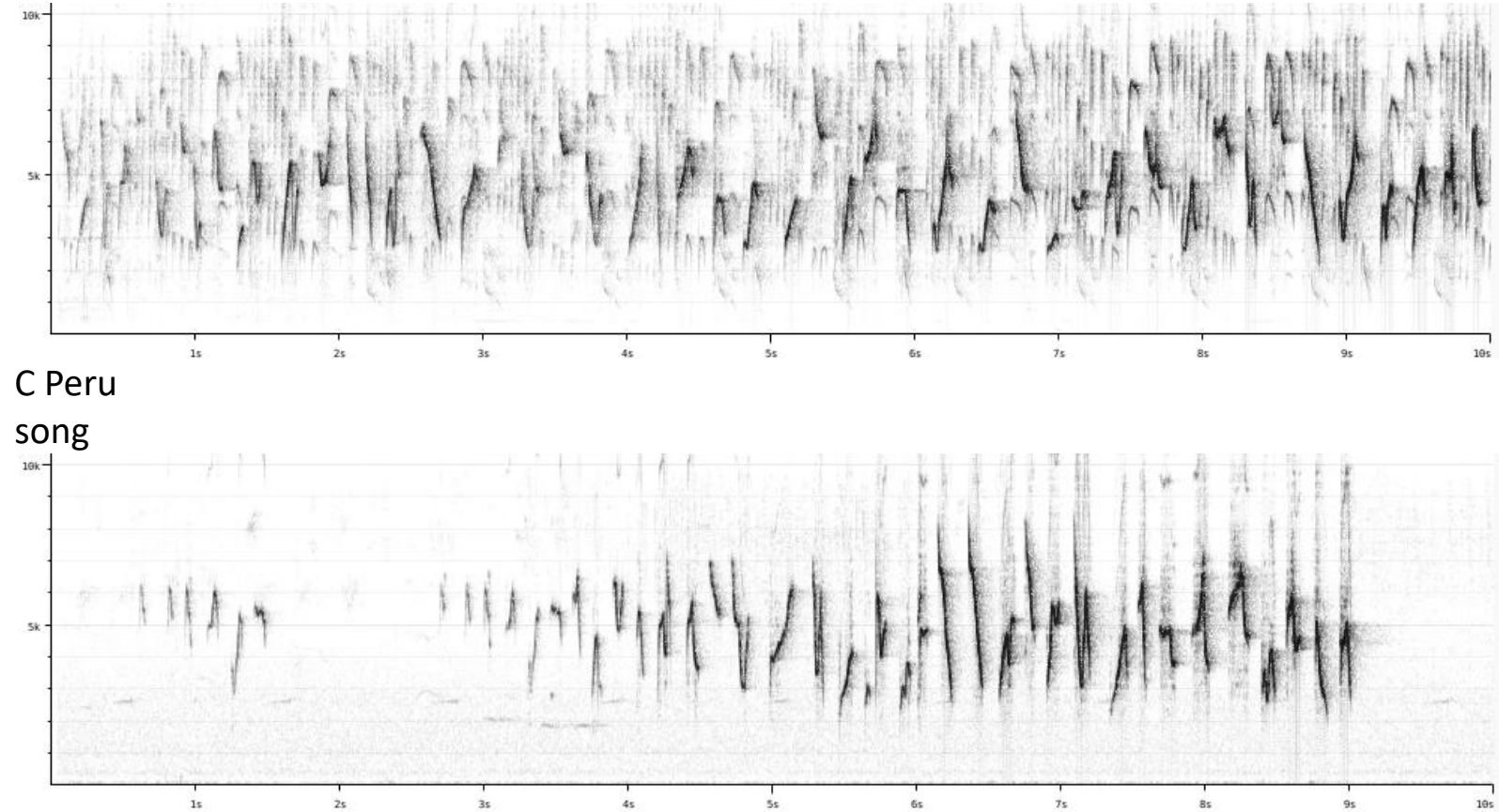




\section{HANDBOOK OF THE \\ BIRDSPFGE WORLD}

duet (song and twitter)

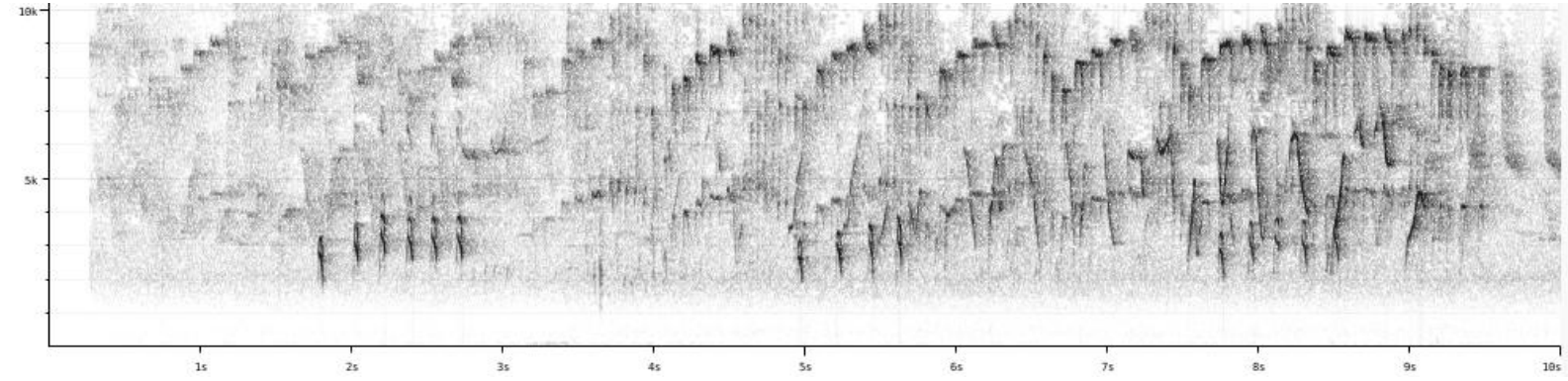

euophrys

song

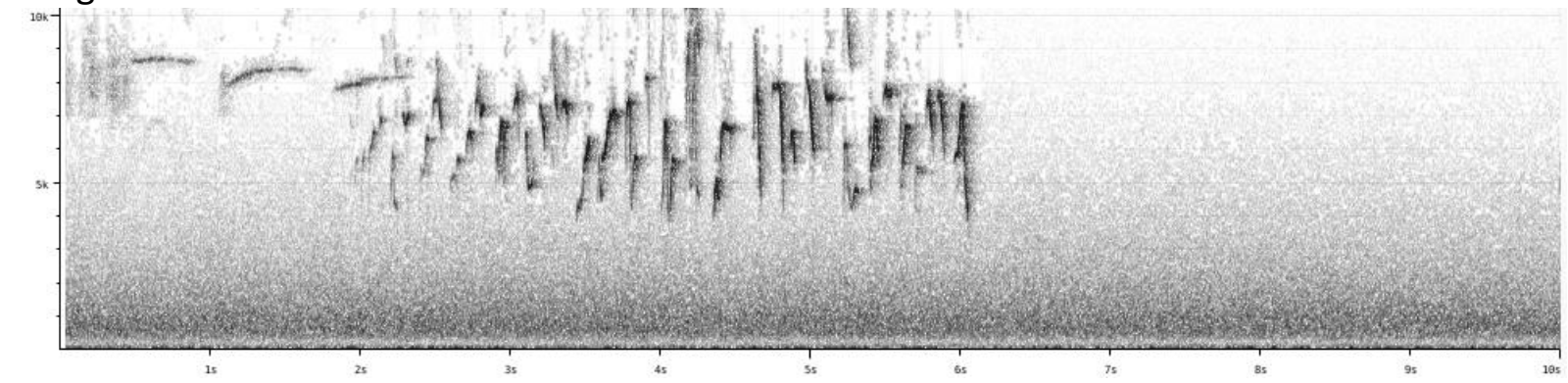

twitter

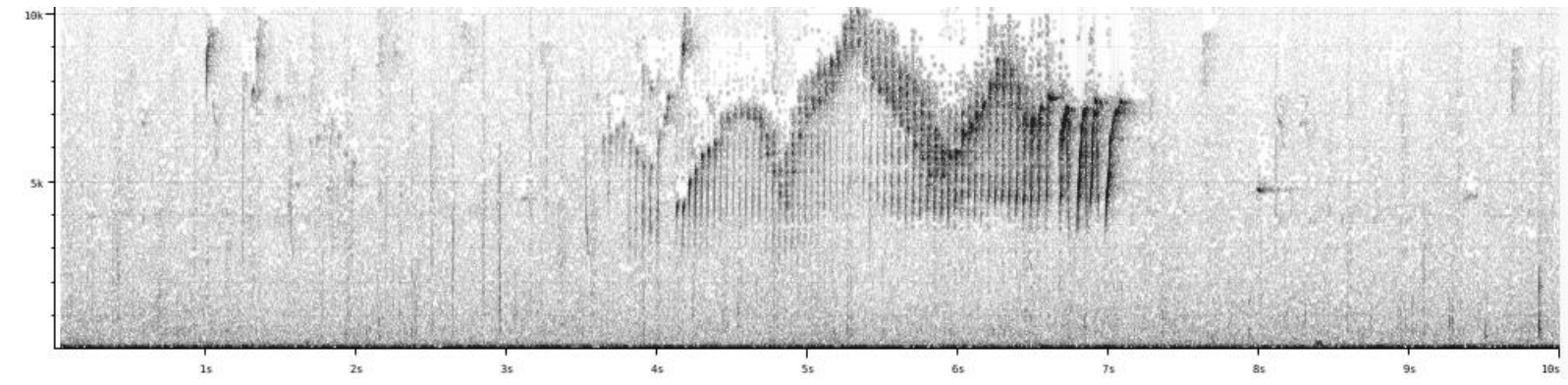

duet (song and twitter)

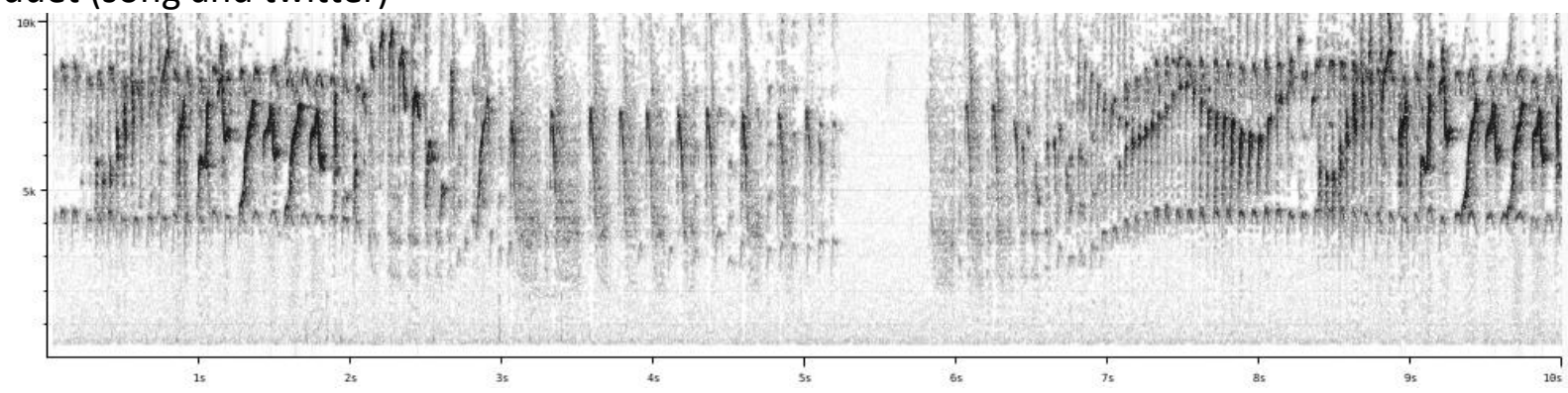

duet (song and twitter)

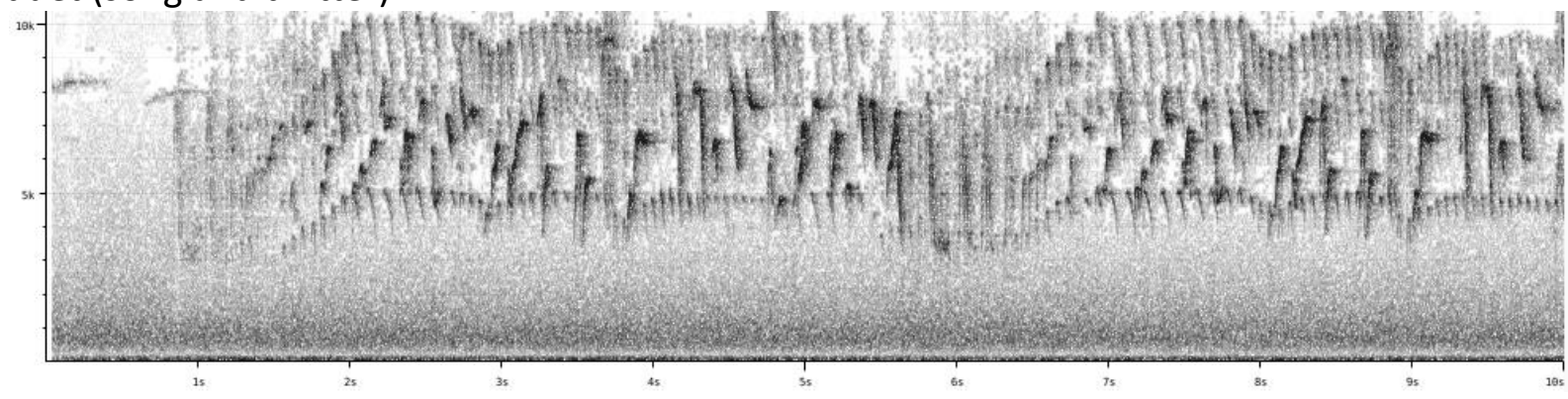



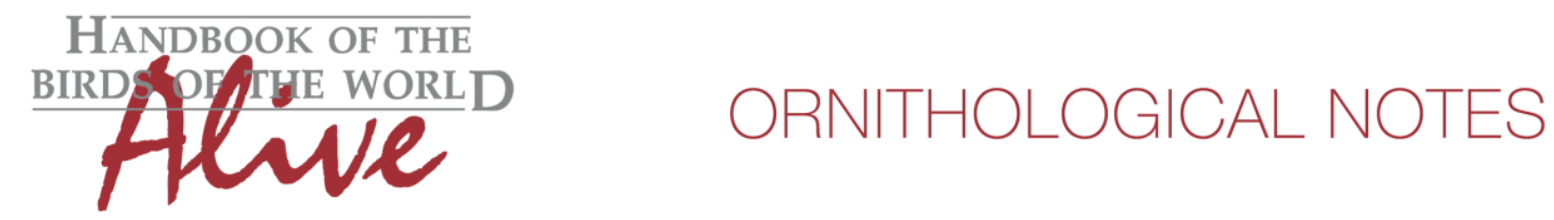

Songs are quite variable, and further complicated by song either given alone or as a duet. There is also a possible identification pitfall with Superciliaried Hemispingus in some regions. A few trends become however apparent:

Song of striaticeps is most characteristic, a fairly long series of well-separated melodious whistles at fairly low pitch (down to $c 2.5 \mathrm{kHz}$ ), gradually increasing in volume (not unlike some Whitestarts Myioborus). In duet, second bird adds a fast higher-pitched twittering with a clear rhythmic pattern (trrrrwhit-tit-tit- trrrrwhit-tit-tit-...).

Song of euophrys somewhat similar in structure, but notes much higher pitched (down to c3.5-4kHz), pace slightly faster and song phrases shorter. In duet, second bird adds a fast long high-pitched twitter going up and down in pitch (also very different from previous).

Song of nominate apparently a fairly short phrase starting with some stuttering and with notes delivered at fast pace, often slightly descending in pitch towards the end and increasing in volume. Duet apparently an entirely different vocalization, a very fast highpitched twittering with some more melodious high-pitched notes mixed in.

Song of richardsoni and quindianus quite similar to nominate, but apparently song phrases somewhat longer in length, with longer stuttering series. Probably not always safely told apart from nominate.

Vocally there is thus a significant difference between striaticeps/euophrys and other races. Main differences being that the former group has a longer song phrase length (2), lack of stuttering start in song (1-2), up and down pattern in pitch of duet twitter (1). Total vocal score about 3-4.

Furthermore striaticeps can easily be told apart from euophrys based on min. frequency of notes in song (2) and repetitive pattern of duet twittering (1-2). Total vocal score about 3.

Nominate may differ from richardsoni and quindianus in shorter song phrase (1-2) and possibly different duet.

A more in depth vocal analysis of this fairly complicated case is highly recommended, and should also include evaluation of the vocal transition of striaticeps/euophrys around Cuzco.

This note was finalized on 7th October 2016, using sound recordings available on-line at that moment. We would like to thank in particular the sound recordists who placed their song recordings for this species on XC and ML: Nick Athanas, Peter Boesman, Thomas Donegan, Ross Gallardy, David Geale, Bennett Hennessey, Sebastian Herzog, Charles Hesse, Olaf Jahn, Niels Krabbe, Phyllis Isler, Frank Lambert, Dan Lane, Mitch Lysinger, Oscar Marin Gomez, Sjoerd Mayer, John V Moore, Ted Parker, Bob Planqué, Mark Robbins, Fabrice Schmitt, Thomas Schulenberg, Paul Schwartz, Andrew Spencer, Joseph Tobias and Charlie Vogt. 


\section{References}

Tobias, J.A., Seddon, N., Spottiswoode, C.N., Pilgrim, J.D., Fishpool, L.D.C. \& Collar, N.J. (2010). Quantitative criteria for species delimitation. Ibis 152(4): 724-746.

\section{Recommended citation}

Boesman, P. (2016). Notes on the vocalizations of Citrine Warbler (Basileuterus luteoviridis). HBW Alive Ornithological Note 438. In: Handbook of the Birds of the World Alive. Lynx Edicions, Barcelona. (retrieved from http://www.hbw.com/node/1284497 on 9 December 2016). 